Marquette University

e-Publications@Marquette

7-30-2011

\title{
Does Physical Activity Influence Semantic Memory Activation in Amnestic Mild Cognitive Impairment?
}

\author{
J. Carson Smith \\ University of Wisconsin - Milwaukee \\ Kristy A. Nielson \\ Marquette University, kristy.nielson@marquette.edu \\ John L. Woodard \\ Wayne State University \\ Michael Seidenberg \\ Rosalind Franklin University of Medicine and Science \\ Matthew D. Verber \\ Medical College of Wisconsin
}

See next page for additional authors

Follow this and additional works at: https://epublications.marquette.edu/psych_fac

Part of the Psychology Commons

\section{Recommended Citation}

Smith, J. Carson; Nielson, Kristy A.; Woodard, John L.; Seidenberg, Michael; Verber, Matthew D.; Durgerian, Sally; Antuono, Piero; Butts, Alissa M.; Hantke, Nathan C.; Lancaster, Melissa A.; and Rao, Stephen M., "Does Physical Activity Influence Semantic Memory Activation in Amnestic Mild Cognitive Impairment?" (2011). Psychology Faculty Research and Publications. 19.

https://epublications.marquette.edu/psych_fac/19 


\section{Authors}

J. Carson Smith, Kristy A. Nielson, John L. Woodard, Michael Seidenberg, Matthew D. Verber, Sally Durgerian, Piero Antuono, Alissa M. Butts, Nathan C. Hantke, Melissa A. Lancaster, and Stephen M. Rao 


\title{
Does Physical Activity Influence Semantic Memory Activation in Amnestic Mild Cognitive Impairment?
}

\author{
J. Carson Smith \\ Department of Health Sciences \\ University of Wisconsin-Milwaukee \\ Milwaukee, WI \\ Kristy A. Nielson \\ Department of Psychology, Marquette University \\ Department of Neurology, Medical College of Wisconsin \\ Milwaukee, WI \\ John L. Woodard \\ Department of Psychology, Wayne State University \\ Detroit, $M I$ \\ Michael Seidenberg \\ Department of Psychology, Rosalind Franklin University of \\ Medicine and Science \\ North Chicago, IL
}


NOT THE PUBLISHED VERSION; this is the author's final, peer-reviewed manuscript. The published version may be accessed by following the link in the citation at the bottom of the page.

\author{
Matthew D. Verber \\ Clinical and Translational Science Institute \\ Medical College of Wisconsin \\ Milwaukee, WI \\ Sally Durgerian \\ Department of Neurology, Medical College of Wisconsin \\ Milwaukee, WI \\ Piero Antuono \\ Department of Neurology, Medical College of Wisconsin \\ Milwaukee, WI \\ Alissa M. Butts \\ Department of Psychology, Marquette University \\ Milwaukee, WI \\ Nathan C. Hantke \\ Department of Psychology, Marquette University \\ Milwaukee, WI \\ Melissa A. Lancaster \\ Department of Psychology, Rosalind Franklin University of \\ Medicine and Science \\ North Chicago, IL \\ Stephen M. Rao \\ Schey Center for Cognitive Neuroimaging \\ Neurological Institute, Cleveland Clinic \\ Cleveland, $\mathrm{OH}$
}

\begin{abstract}
The effect of physical activity (PA) on functional brain activation for semantic memory in amnestic mild cognitive impairment (aMCI) was examined using event-related fMRI during fame discrimination. Greater semantic memory activation occurred in the left caudate of High- versus LowPA patients $(P=0.03)$, suggesting PA may enhance memory-related caudate activation in aMCI.
\end{abstract}

Keywords: Exercise, Alzheimer's Disease, Cognition

Psychiatry Research: Neuroimaging, Vol 193, No. 1 (July 30, 2011): pg. 60-62. DOI. This article is (C Elsevier and permission has been granted for this version to appear in e-Publications@Marquette. Elsevier does not grant permission for this article to be further copied/distributed or hosted elsewhere without the express permission from Elsevier. 


\section{Introduction}

Amnestic mild cognitive impairment (aMCI) is a high risk state for Alzheimer's disease (AD), with $80 \%$ progressing to AD over a 6 year period (Petersen et al., 2001). Effective therapies are needed for preserving cognitive and brain function in aMCI. Physical activity (PA) has been promoted as one such promising intervention (Baker et al., 2010; Smith et al., 2011). PA enhances neuropsychological test performance in healthy older adults (Lautenschlager et al., 2008), improves semantic memory retrieval in aMCI patients (Baker et al., $\underline{2010}$ ), and is associated with greater semantic memory-related brain activation in healthy older adults, particularly in those carrying increased AD risk from the apolipoprotein E-epsilon4 (APOE-ع4) allele (Smith et al., 2011). The objective of this study was to expand the literature by examining the effects of PA on brain activation during semantic memory in aMCI patients. Based on our previous findings, we hypothesized greater PA would be associated with greater activation in aMCI.

\section{Method}

Eighteen participants who met Petersen criteria (Petersen et al., 2001) for aMCI were studied. A comprehensive neuropsychological battery was administered (see Table S1; (Smith et al., 2011). Frequency and intensity of leisure-time PA was measured using the Stanford Brief Activity Survey (SBAS) (Taylor-Piliae et al., 2006). Participants indicating $\leq 2$ days of low-intensity PA were classified as Low-PA $(n=9)$ while participants indicating $\geq 3$ days per week of moderate to vigorous PA were classified as High-PA $(n=9)$. The Institutional Review Board at the Medical College of Wisconsin approved the study, and written informed consent was obtained according to the Declaration of Helsinki.

Whole-brain, event-related fMRI was conducted on a General Electric (Waukesha, WI) Signa Excite 3.0 Tesla scanner using an echoplanar pulse sequence and high-resolution, three-dimensional spoiled gradient-recalled at steady-state (SPGR) anatomic images (Smith et al., 2011). The semantic memory task included 30 names of famous persons (e.g., Frank Sinatra) and 30 names of non-famous 
individuals where each name was presented for $4 \mathrm{~s}$ and participants indicated famous or unfamiliar by finger key-press (Douville et al., 2005). The 60 name trials were randomly interspersed with $204-5$ fixation trials. The imaging run began and ended with $12 \mathrm{~s}$ of fixation (run-time $344 \mathrm{~s}$ ).

Functional images were analyzed with AFNI (Cox, 1996). Deconvolution was used to extract separate hemodynamic response functions (HRFs, 0-16 s post-stimulus) for famous and unfamiliar names from the time-series (correct trials only). Area under the curve (AUC) was calculated by summing the HRFs at 4, 6, and 8 s post-trial onset. Statistical parametric maps were generated for each group where the \%AUC for famous names differed significantly from unfamiliar names. An individual voxel probability threshold ( $\mathrm{t}(6)=$ 4.308, $P<0.005$ ) was coupled with a minimum cluster volume threshold of $0.731 \mathrm{ml}$, equivalent to a whole brain family-wise error threshold of $p<.05$. A functional region of interest (fROI) analysis was conducted to evaluate potential group differences in the magnitude of the BOLD response in functionally active regions. A fROI map was generated for the combined sample using a disjunction mask. Any voxel deemed "activated" by the Famous-Unfamiliar name subtraction in at least one of the two groups contributed to the final fROI map. For each participant, an "averaged HRF" was calculated for all voxels within a fROI. AUC $(4,6$, and $8 \mathrm{~s}$ post stimulus onset) in each fROI served as the dependent variable (see Smith et al., 2011). One-way ANOVA was used to compare \%AUC in each fROI between PA groups with a one-tailed level of significance of $P<0.05$.

\section{Results}

The High-PA and Low-PA groups did not differ significantly in age, sex, education, family history of AD, APOE gene status, depressive symptoms, neuropsychological performance, or fame discrimination performance ( $>86 \%$ for both groups) (see Table S1). The volume of activation was $25 \%$ greater in the High-PA group (see Figure S1 and Table S2). Brain activation related to semantic memory processing (famous > unfamiliar) occurred in 6 fROIs. High-PA aMCI showed significantly greater intensity of activation in the left caudate compared to Low-PA aMCI (Mean ( $($ SD): High-PA $=0.358$ (0.151\%);

Psychiatry Research: Neuroimaging, Vol 193, No. 1 (July 30, 2011): pg. 60-62. DOI. This article is (C Elsevier and permission has been granted for this version to appear in e-Publications@Marquette. Elsevier does not grant permission for this article to be further copied/distributed or hosted elsewhere without the express permission from Elsevier. 
Low-PA $\left.=0.149(0.268 \%) ; F(1,16)=4.117, P=0.03 ; \eta^{2}{ }_{p}=0.205\right)$ (see Figure 1). Comparisons of the volume of the caudate nuclei demonstrated no group difference.

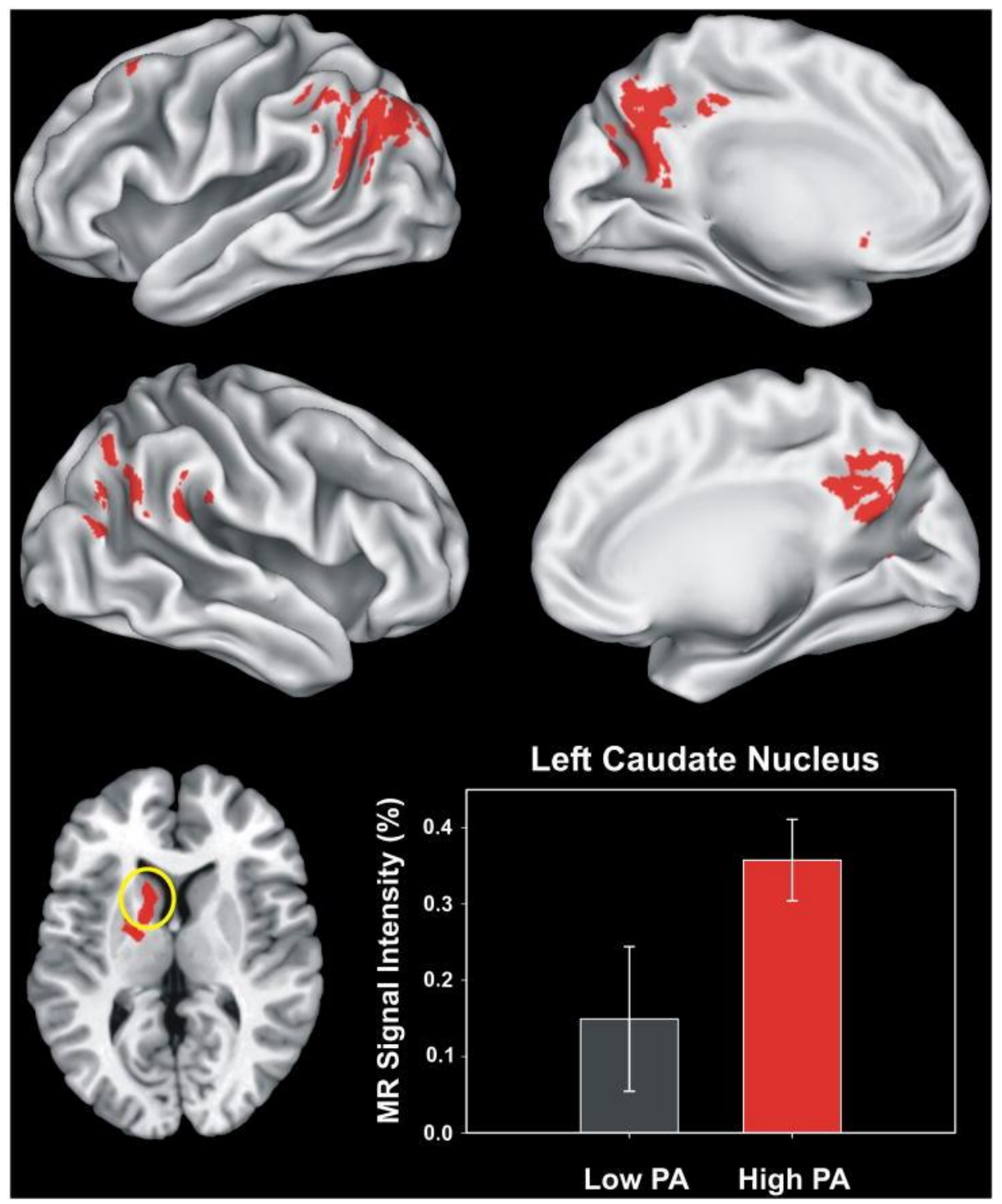

Figure 1. Functional Regions of Interest (fROIs) derived from all regions activated in both groups based on the voxelwise analysis (see supplementary Figure S1 and Table S2). The six regions of interest are shown in the top (left hemisphere) and middle (right hemisphere) panels. The two groups significantly differed only in activation (Famous > Unfamiliar) of the left caudate region (circled in yellow, axial view in the lower left panel, $z=+10 \mathrm{~mm}$ superior to the AC-PC line). The MR signal intensity difference (\%AUC) between the Low-PA and High-PA groups in the left caudate region is shown in the lower right panel. Error bars = SEM. 


\section{Discussion}

These findings provide preliminary evidence that greater leisuretime physical activity is positively related to a greater general spatial extent of semantic memory activation and a greater intensity of activation in the left caudate in patients diagnosed with aMCI. It has been suggested that the caudate participates in a variety of cognitive functions through the augmentation of intentional actions and cognitions, and the inhibition of competing motor programs and cognitive networks through closed loops that involve other basal ganglia structures and several frontal cortical regions (Crosson et al., 2007). The direct (augmentative) cortical loops are modulated by dopamine D1 receptor activity increasing the signal-to-noise ratio on the outputs of striatal spiny neurons. It has been suggested that D1 receptors serve to facilitate cognition by helping to prolong the activation of the cortical loops that support them (Crosson et al., 2007).

Changes in caudate volume are reportedly involved in the progression of MCI and may be affected by AD pathology (Smith et al., 2006; Hakamata et al., 2010). Our finding suggests that being physically active may help preserve activation of the caudate during semantic memory retrieval. While the mechanism for this effect is not clear, we hypothesize that PA may increase dopaminergic input (de Castro and Duncan, 1985) that augments the gain among frontostriatal closed loop networks and results in enhanced activation of the caudate during semantic memory retrieval (Crosson et al., 2007).

In previous work, greater physical fitness was related to larger left caudate volume in healthy, 9-10 year old children, although it was unrelated to flanker task performance (Browning, 2010). Baker et al. (2010) compared aerobic exercise training to a stretching control group in 33 aMCI patients and reported that exercise improved category fluency, an index of semantic memory retrieval. The current findings provide the first evidence of an association between functional activation the left caudate during semantic memory and greater levels of PA in aMCI patients. These findings extend our previous report that enhanced semantic memory processing was observed in more

Psychiatry Research: Neuroimaging, Vol 193, No. 1 (July 30, 2011): pg. 60-62. DOI. This article is (C Elsevier and permission has been granted for this version to appear in e-Publications@Marquette. Elsevier does not grant permission for this article to be further copied/distributed or hosted elsewhere without the express permission from Elsevier. 
physically active cognitively intact older adults, particularly in individuals who possessed the APOE-ع4 allele (Smith et al., 2011). While that study did not report caudate activation, our earlier work demonstrated caudate activation by our task in both cognitively intact adults (Seidenberg et al., 2009) and MCI patients (Woodard et al., $\underline{2009)}$.

An important question is whether greater semantic memory activation reflects a compensatory response indicative of future cognitive decline, or whether this effect reflects a cognitive reserve that may be protective. In a longitudinal study of cognitively intact individuals at risk for developing $A D$, we showed that greater baseline fMRI semantic memory activation during famous name recognition was protective against cognitive decline 18 months later (Woodard et al., 2010). Collectively, these findings indicate physical activity may enhance semantic memory activation in healthy older adults at risk for $A D$, and that these effects may be limited to the caudate nucleus in cognitively impaired older adults. Whether PA provides protection against future cognitive decline in aMCI is currently unknown.

Because the activations for the famous and unfamiliar names were subtracted, our finding cannot be attributed to common motor or sensory activation related to the visual perception of the names and the motor response. The groups were also equivalent on multiple demographic and cognitive performance factors, APOE status, and caudate volume. It is conceivable that other unmeasured factors, such as overall metabolic health, microvascular pathology, or other cognitive domains (e.g., executive function), differed between the two groups (see Figure S1 and Table S2). This study is also limited by its cross-sectional design, its small sample, and the use of a self-report measure of leisure-time PA. We did not assess cardiorespiratory fitness. It is possible that the group differences in brain activation may result from increased cerebral perfusion and/or increased cerebral blood volume associated with PA (Pereira et al., 2007). It is important to note, however, that responses on the SBAS have been shown to be dose-dependently related to cardiovascular risk biomarkers and estimated energy expenditure (Taylor-Piliae et al., 2006).

In our previous studies of cognitively intact older adults at increased risk for $A D, P A$ was related to greater volume and intensity

Psychiatry Research: Neuroimaging, Vol 193, No. 1 (July 30, 2011): pg. 60-62. DOI. This article is (C Elsevier and permission has been granted for this version to appear in e-Publications@Marquette. Elsevier does not grant permission for this article to be further copied/distributed or hosted elsewhere without the express permission from Elsevier. 
NOT THE PUBLISHED VERSION; this is the author's final, peer-reviewed manuscript. The published version may be accessed by following the link in the citation at the bottom of the page.

of semantic memory activation (Smith et al., 2011), and greater semantic memory activation was a sign of cognitive stability over 18 months (Woodard et al., 2010). In this cross-sectional study in aMCI patients, we found that greater PA was associated with greater overall volume of activation and greater intensity of activation in the left caudate during semantic memory processing. However, it is not known if the ability to activate the caudate is protective against future decline in aMCI or if PA prospectively enhances brain function in aMCI and reduces conversion to $A D$. These hypotheses need to be tested prospectively in a larger sample of aMCI patients. 
NOT THE PUBLISHED VERSION; this is the author's final, peer-reviewed manuscript. The published version may be accessed by following the link in the citation at the bottom of the page.

\section{Supplementary Material}

Table S1. Participant Characteristics and Task Performance. Mean (SD) demographic characteristics, neuropsychological test results, and fMRI task performances for the two patient groups. Results of one-way ANOVAs are summarized by $t$-statistics ( $d f=$ $17), P$-values, and associated effect sizes $\left(\eta^{2} p\right)$. No significant group differences emerged on any of the variables.

\begin{tabular}{|c|c|c|c|c|c|}
\hline \multirow[b]{2}{*}{ Variables } & \multicolumn{2}{|c|}{ Physical Activity Status } & \multirow[b]{2}{*}{$t$} & \multirow[b]{2}{*}{$P$} & \multirow[b]{2}{*}{$\eta^{2} p$} \\
\hline & $\begin{array}{l}\text { Low PA } \\
(n=9)\end{array}$ & $\begin{array}{l}\text { High PA } \\
(n=9)\end{array}$ & & & \\
\hline \multicolumn{6}{|l|}{ Demographics } \\
\hline Age (yrs) & $73.6(8.3)$ & $75.0(5.5)$ & 0.43 & .67 & .01 \\
\hline Education (yrs) & $14.7(1.7)$ & $16.1(3.2)$ & 1.16 & .27 & .08 \\
\hline Gender & $2 M, 7 F$ & $2 M, 7 F$ & -- & 1.0 & -- \\
\hline APOE gene status $(n)$ & 4 e4 $\square$ & 4 e4 $\square$ & 0.0 & 1.0 & -- \\
\hline Acetylcholinesterase use $(n)$ & 2 & 5 & & & \\
\hline \multicolumn{6}{|l|}{ Neuropsychological Testing } \\
\hline MMSE & $27.1(2.0)$ & $27.1(2.0)$ & 0.0 & 1.0 & -- \\
\hline DRS Attention & $35.4(1.9)$ & $36.2(0.8)$ & 1.14 & .28 & .07 \\
\hline DRS I/P & $34.1(2.5)$ & $35.2(2.8)$ & 0.89 & .39 & .05 \\
\hline DRS Memory & $20.1(2.6)$ & $18.7(4.6)$ & 0.82 & .42 & .04 \\
\hline DRS Total & $132.4(5.5)$ & $132.7(6.5)$ & 0.08 & .94 & $<.01$ \\
\hline AVLT Trials 1-5 & $29.7(8.9)$ & $30.1(8.0)$ & 0.11 & .91 & $<.01$ \\
\hline AVLT DR & $3.3(2.3)$ & $2.8(1.4)$ & 0.61 & .55 & .02 \\
\hline AVLT LTPR & $46.5(30.9)$ & $39.8(22.0)$ & 0.52 & .61 & .02 \\
\hline GDS & $5.4(3.6)$ & $4.6(4.9)$ & 0.43 & .67 & .01 \\
\hline \multicolumn{6}{|l|}{ fMRI Task Performance } \\
\hline$\%$ Correct Famous & $86.3(17.2)$ & $88.9(13.1)$ & 0.36 & .72 & $<.01$ \\
\hline$\%$ Correct Unfamiliar & $95.2(7.1)$ & $92.2(8.7)$ & 0.79 & .44 & .04 \\
\hline RT Famous (ms) & $1319(276)$ & $1306(227)$ & 0.10 & .92 & $<.01$ \\
\hline RT Unfamiliar (ms) & $1609(361)$ & $1730(303)$ & 0.78 & .45 & .04 \\
\hline
\end{tabular}

Psychiatry Research: Neuroimaging, Vol 193, No. 1 (July 30, 2011): pg. 60-62. DOI. This article is (C Elsevier and permission has been granted for this version to appear in e-Publications@Marquette. Elsevier does not grant permission for this article to be further copied/distributed or hosted elsewhere without the express permission from Elsevier. 
NOT THE PUBLISHED VERSION; this is the author's final, peer-reviewed manuscript. The published version may be accessed by following the link in the citation at the bottom of the page.

Initiation/Perseveration; AVLT $=$ Rey Auditory Verbal Learning Test; $\mathrm{DR}=$ Delayed Recall; LTPR = Long-term percent retention; GDS = Geriatric Depression Scale; RT = reaction time.

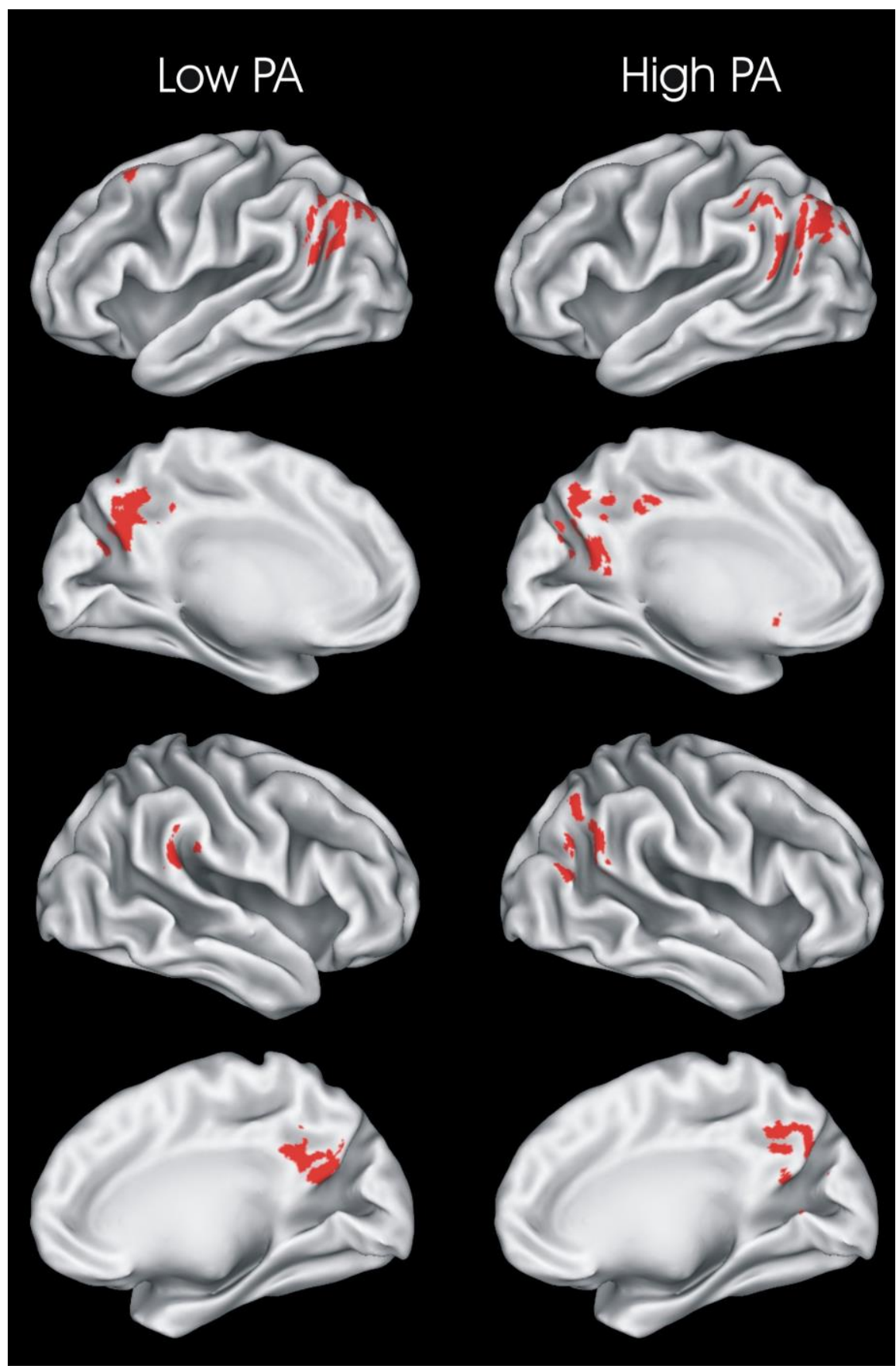

Figure S1. Results of voxelwise analysis showing brain regions demonstrating significant differences between Famous and Unfamiliar name conditions for each of the two aMCI groups (left $=$ Low PA; right $=$ High PA). Areas in red indicate Famous $>$

Psychiatry Research: Neuroimaging, Vol 193, No. 1 (July 30, 2011): pg. 60-62. DOI. This article is (C) Elsevier and permission has been granted for this version to appear in e-Publications@Marquette. Elsevier does not grant permission for this article to be further copied/distributed or hosted elsewhere without the express permission from Elsevier. 
NOT THE PUBLISHED VERSION; this is the author's final, peer-reviewed manuscript. The published version may be accessed by following the link in the citation at the bottom of the page.

Unfamiliar. There were no areas where Unfamiliar > Famous. Location and volume of activation foci delineated in Table S2. PA = physical activity.

\section{Acknowledgments}

The authors thank Qi Zhang and Amelia Gander for their help with subject recruitment and data collection. This project was supported by NIH grant, R01 AG022304, awarded to SMR, the Medical College of Wisconsin General Clinical Research Center (M01 RR00058), and the Medical College of Wisconsin Advancing a Healthier Wisconsin Program. The content is solely the responsibility of the authors and does not necessarily represent the official views of the National Institute on Aging or the National Institutes of Health.

Publisher's Disclaimer: This is a PDF file of an unedited manuscript that has been accepted for publication. As a service to our customers we are providing this early version of the manuscript. The manuscript will undergo copyediting, typesetting, and review of the resulting proof before it is published in its final citable form. Please note that during the production process errors may be discovered which could affect the content, and all legal disclaimers that apply to the journal pertain.

\section{References}

Baker LD, Frank LL, Foster-Schubert K, Green PS, Wilkinson CW, McTiernan A, Plymate SR, Fishel MA, Watson GS, Cholerton BA, Duncan GE, Mehta PD, Craft S. Effects of aerobic exercise on mild cognitive impairment: A controlled trial. Archives of Neurology. 2010;67:71-79.

Browning GG. A sign guideline that has considerable interpretation bias. Clinical Otolaryngology. 2010;35:325-326.

Cox RW. Afni: Software for analysis and visualization of functional magnetic resonance neuroimages. Computers and Biomedical Research. $1996 ; 29: 162-173$.

Crosson B, Benjamin M, Levy I. Role of the basal ganglia in language and semantics: Supporting cast. In: Hart J Jr, Kraut MA, editors. Neural basis of semantic memory. New York: Cambridge University Press; 2007. pp. 219-243.

de Castro JM, Duncan G. Operantly conditioned running: Effects on brain catecholamine concentrations and receptor densities in the rat. Pharmacology Biochemistry \& Behavior. 1985;23:495-500.

Douville K, Woodard JL, Seidenberg M, Miller SK, Leveroni CL, Nielson KA, Franczak M, Antuono P, Rao SM. Medial temporal lobe activity for recognition of recent and remote famous names: An event-related fmri study. Neuropsychologia. 2005;43:693-703.

Psychiatry Research: Neuroimaging, Vol 193, No. 1 (July 30, 2011): pg. 60-62. DOI. This article is (C) Elsevier and permission has been granted for this version to appear in e-Publications@Marquette. Elsevier does not grant permission for this article to be further copied/distributed or hosted elsewhere without the express permission from Elsevier. 
Hakamata Y, Lissek S, Bar-Haim Y, Britton JC, Fox NA, Leibenluft E, Ernst M, Pine DS. Attention bias modification treatment: A meta-analysis toward the establishment of novel treatment for anxiety. Biological Psychiatry. 2010;68:982-990.

Lautenschlager NT, Cox KL, Flicker L, Foster JK, van Bockxmeer FM, Xiao J, Greenop KR, Almeida OP. Effect of physical activity on cognitive function in older adults at risk for alzheimer disease: A randomized trial. Journal of the American Medical Association. 2008;300:10271037.

Pereira AC, Huddleston DE, Brickman AM, Sosunov AA, Hen R, McKhann GM, Sloan R, Gage FH, Brown TR, Small SA. An in vivo correlate of exercise-induced neurogenesis in the adult dentate gyrus. Proceedings of the National Academy of Science USA. 2007;104:5638-5643.

Petersen RC, Doody R, Kurz A, Mohs RC, Morris JC, Rabins PV, Ritchie K, Rossor $M$, Thal $L$, Winblad $B$. Current concepts in mild cognitive impairment. Archives of Neurology. 2001;58:1985-1992.

Seidenberg M, Guidotti L, Nielson KA, Woodard JL, Durgerian S, Antuono P, Zhang Q, Rao SM. Semantic memory activation in individuals at risk for developing alzheimer disease. Neurology. 2009;73:612-620.

Smith AG, Russell J, Feldman EL, Goldstein J, Peltier A, Smith S, Hamwi J, Pollari D, Bixby B, Howard J, Singleton JR. Lifestyle intervention for pre-diabetic neuropathy. Diabetes Care. 2006;29:1294-1299.

Smith JC, Nielson KA, Woodard JL, Seidenberg M, Durgerian S, Antuono P, Butts AM, Hantke NC, Lancaster MA, Rao SM. Interactive effects of physical activity and apoe-epsilon4 on bold semantic memory activation in healthy elders. NeuroImage. 2011;54:635-644.

Taylor-Piliae RE, Norton LC, Haskell WL, Mahbouda MH, Fair JM, Iribarren C, Hlatky MA, Go AS, Fortmann SP. Validation of a new brief physical activity survey among men and women aged 60-69 years. American Journal of Epidemiology. 2006;164:598-606.

Woodard J, Seidenberg M, Nielson KA, Smith JC, Antuono P, Durgerian S, Guidotti L, Zhang Q, Butts A, Hantke N, Lancaster M, Rao SM. Prediction of cognitive decline in healthy older adults using fmri. Journal of Alzheimer's Disease. 2010;21:871-885.

Woodard JL, Seidenberg M, Nielson KA, Antuono P, Guidotti L, Durgerian S, Zhang Q, Lancaster M, Hantke N, Butts A, Rao SM. Semantic memory activation in amnestic mild cognitive impairment. Brain. 2009;132:2068-2078.

Psychiatry Research: Neuroimaging, Vol 193, No. 1 (July 30, 2011): pg. 60-62. DOI. This article is (C Elsevier and permission has been granted for this version to appear in e-Publications@Marquette. Elsevier does not grant permission for this article to be further copied/distributed or hosted elsewhere without the express permission from Elsevier. 